\title{
FRUIT FLIES AND THEIR PARASITOIDS IN THE FRUIT GROWING REGION OF LIVRAMENTO DE NOSSA SENHORA, BAHIA, WITH RECORDS OF UNPRECEDENTED INTERACTIONS ${ }^{1}$
}

\author{
SUZANY AGUIAR LEITE ${ }^{2}$, MARIA APARECIDA CASTELLANI ${ }^{3}$, \\ ANA ELIZABETE LOPES RIBEIRO ${ }^{4}$, DANIELA RIBEIRO DA COSTA ${ }^{2}$, \\ MARIA APARECIDA LEÃO BITTENCOURT ${ }^{5}$, ALDENISE ALVES MOREIRA ${ }^{3}$
}

ABSTRACT- Several fruit fly species (Diptera: Tephritidae and Lonchaeidae) assume the status of primary pests in fruit trees grown in Brazil, causing direct production losses. The aims of the study were to know aspects of diversity of fruit flies and their parasitoids in the fruit growing region of Livramento de Nossa Senhora, Bahia. Fruit samples were collected from 19 plant species during November/2011 and June/2014. Infestation rates were calculated in pupae. $\mathrm{kg}^{-1}$ of fruit and pupae.fruit ${ }^{-1}$. The results indicate the occurrence of Anastrepha obliqua (Macquart), Ceratitis capitata (Wiedemann) and Neosilba pendula (Bezzi). Plant species Anacardium occidentale, Averrhoa carambola, Carica papaya, Eugenia uniflora, Malpighia emarginata, Mangifera indica var. "Haden", "Rosa" and "Tommy Atkins", Opuntia ficus indica, Pereskia bahiensis, Psidium guajava, Spondias lutea, Spondias purpurea and Spondias tuberosa are hosts of fruit flies in the region. Unprecedented bitrophic relationships between P. bahiensis and C. capitata and Anastrepha sp. and between Opuntia ficus indica and C. capitata and A. obliqua were recorded. Unprecedented tritrophic relationship for the state of Bahia Averrhoa carambola and C. capitata and parasitoid of the Pteromalidae Family were also recorded. Tritrophic associations between $M$. indica var. "Tommy Atkins" and S. purpurea and A. obliqua and Doryctobracon areolatus; and between S. purpurea and A. obliqua and Utetes anastrephae were observed.

Index terms: Anastrepha obliqua. Cactaceae. Ceratitis capitata. Doryctobracon aureolatus. Neosilba pendula.

\section{MOSCAS FRUGÍVORAS E SEUS PARASITOIDES NO POLO DE FRUTICULTURA DE LIVRAMENTO DE NOSSA SENHORA, BAHIA, COM REGISTRO DE INTERAÇÕES INÉDITAS}

\begin{abstract}
RESUMO- Várias espécies de moscas frugívoras (Diptera: Tephritidae e Lonchaeidae) assumem o status de pragas primárias em fruteiras cultivadas no Brasil, determinando prejuízos diretos à produção. $\mathrm{O}$ objetivo do trabalho foi conhecer aspectos da diversidade de moscas frugívoras e seus parasitoides no polo de fruticultura de Livramento de Nossa Senhora-BA. Foram realizadas amostragens de frutos em 19 espécies vegetais durante novembro/2011 e junho/2014. Foram calculados os índices de infestação em pupário. $\mathrm{kg}^{-1}$ de fruto e pupário.fruto ${ }^{-1}$. Os resultados indicaram a ocorrência de Anastrepha obliqua (Macquart), Ceratitis capitata (Wiedemann) e Neosilba pendula (Bezzi). As espécies vegetais Anacardium occidentale, Averrhoa carambola, Carica papaya, Eugenia uniflora, Malpighia emarginata, Mangifera indica var. "Haden", "Rosa" e "Tommy Atkins", Opuntia ficus indica, Pereskia bahiensis, Psidium guajava, Spondias lutea, Spondias purpurea e Spondias tuberosa são hospedeiros de moscas frugívoras na região. Registram-se, as relações bitróficas inéditas entre P. bahiensis e C. capitata e Anastrepha sp.; e entre Opuntia fícus indica e C. capitata e Anastrepha obliqua. Registra-se a relação tritrófica inédita para o Estado da Bahia A. carambola e C. capitata e parasitoide da Família Pteromalidae. Foram contatadas, também, as associações tritróficas entre $M$. indica var. "Tommy Atkins" e $S$. purpurea e A. obliqua e Doryctobracon areolatus; e entre S. purpurea e A. obliqua e Utetes anastrephae.
\end{abstract}

Termos para indexação: Anastrepha obliqua. Cactáceas. Ceratitis capitata. Doryctobracon aureolatus. Neosilba pendula.

\footnotetext{
1(Paper 074-16). Received May 30, 2016. Accepted: September 16, 2016.

${ }^{2} \mathrm{PhD}$ student. Graduate Program in Agronomy (Plant Technology), UESB, Vitória da Conquista-BA. E-mail: suzanyleite@yahoo.com. br; danielaribeirodacosta@yahoo.com.br

${ }^{3}$ Professors of the State University of Southwestern Bahia, UESB, Department of Plant Science and Animal Science, Vitória da Conquista-BA. E-mail: castellani@uesb.edu.br; aldenise.moreira@gmail.com

${ }^{4}$ Assistant Professor, Federal University of Western Bahia, UFOB, Barra-BA. E-mail: ana.lopes@ufob.edu.br

${ }^{5}$ Professor at the State University of Santa Cruz, UESC, Ilhéus-BA. E-mail: malbitte@uesb.br
} 


\section{INTRODUCTION}

Brazil is the third largest world's fruit producer. Fruit flies (Diptera: Tephritidae) are the main pests of the world's fruit production, considering the direct damage they cause and the capacity to adapt to other regions when introduced (DIAS et al., 2013). In Brazil, fruit flies are recognized as one of the greatest pests of the fruit growing activity, especially when fruits produced are aimed at external market (SÁ et al., 2008). The fruit fly species of economic importance are distributed in the genera Anastrepha Schiner (1868) and Ceratitis MacLeay (1829). The several Anastrepha species is native to the American continent, while Ceratitis capitata (Wiedemann, 1824), known as the Mediterranean fly, is the only representative of the genus Ceratitis in the country, originated from the African continent (FEITOSA et al., 2008).

Anastrepha fraterculus (Wiedemann, 1830) and $A$. obliqua species are the most economically important occurring species in the whole country, mainly infesting plants of the Anarcadiaceae and Myrtaceae families.

Although a large part of the economic damage caused by insects in Brazilian fruit crops is due to the attack of tephritid species Anastrepha spp. and $C$. capitata (SOUZA FILHO et al., 2000), lonchaeidae (Diptera: Lochaeidae), also stand out as primary pest in fruit trees such as acerola (ARAÚJO; ZUCCHI, 2002).

The main quarantine barriers to be overcome by the Brazilian fruit growing sector are phytosanitary. Population monitoring allows knowing the most frequent fly species, population densities and fluctuations and levels of control, aspects that serve as a subsidy to fruit growers for the adoption of control measures (NASCIMENTO et al., 2000).

The structure of the communities of frugivorous flies, their natural enemies and their relationships with host fruits vary among agroecosystems (BITTENCOURT et al., 2012), and this knowledge is of fundamental importance for the management of fruit fly species fruit growing regions of northeastern Brazil, where $C$. capitata is the predominant species in several fruit crops (SÁ et al., 2008). The adaptive capacity of $C$. capitata is related to several hosts in Brazil, either exotic or native. According to Zucchi (2012), C. capitata attacks 89 plant species, demonstrating that it is well suited to different environments. For Aguiar (2012), C. capitata exerts a strong competition with Anastrepha species, favoring its expansion with competitiveness by food niche.
The aim of this study was to know aspects of the diversity of frugivorous flies (Tephritidae and Lonchaeidae) and their parasitoids in several plant species in the fruit growing region of Livramento de Nossa Senhora, Bahia, as subsidies to improve the methods of control of these pests.

\section{MATERIAL AND METHODS}

Studies were carried out in commercial mango orchards and in their vicinities, located in the municipality of Livramento de Nossa Senhora, BA and in the facilities of the Laboratory of Fruit Flies of the State University of Southwestern Bahia, campus of Vitória da Conquista, BA, from November 2011 to June 2014. The municipality of Livramento de Nossa Senhora is located in a region called "Polígono das Secas" (Drought Polygon), in the semi-arid region of Bahia. It is located at coordinates $13^{\circ} 15^{\prime} \mathrm{S}$ and $41^{\circ} 50^{\prime} \mathrm{W}$, with average annual rainfall of $760 \mathrm{~mm}$ and mean annual temperature of $22.6^{\circ} \mathrm{C}$ (SEI, 2015).

The collection of mature fruits from plant and soil, according to their availability, was performed in 27 hosts, comprising 19 plant species and six mango varieties (Table 1).

The methodology of packaging and processing of fruits was performed according to Nascimento et al. (2000) and Silva et al. (2011a). After collection, fruits were sent to the laboratory for counting, weighing and packing in plastic trays containing vermiculite as substrate for larvae pupation. Samples were maintained under ambient and humidity temperature conditions. Processing was performed after 12-13 days with fruits at the rotting stage. Fruits were examined with the aid of a sharp knife, aiming at the location of late larvae and later discarded. The vermiculite was sieved to obtain puparia, which were individualized and transferred to transparent plastic tubes, containing a thin layer of vermiculite for the emergence of adults, both of fruit flies and parasitoids. The emerged specimens were counted and stored in tubes with $70 \%$ alcohol for further identification.

The emerged flies of the C. capitata species were separated and counted and Anastrepha species were identified by the aculeus tip, prepared according to methodology described by Zucchi (2000). Lonchaeidae were identified by the taxonomist MSc Pedro Carlos Stricks. For the identification of parasitoids, the key of Marinho et al. (2011) was used.

The genus Pereskia was identified by taxonomist $\mathrm{PhD}$ Avaldo de Oliveira Soares Filho, from the Department of Natural Sciences - State 
University of Southwestern Bahia - UESB, Campus of Vitória da Conquista. The material was herborized and deposited in the Herbarium collection of the State University of Southwestern Bahia, Campus of Vitoria da Conquista, under identification code HUESBVC8198.

The infestation rates were calculated in pupae. $\mathrm{kg}^{-1}$ of fruit and pupae.fruit ${ }^{-1}$.

\section{RESULTS AND DISCUSSION}

A total of 23,371 fruits in plants and soil of 27 hosts were collected, totaling $1,747.04 \mathrm{~kg}$ (Table 2). A total of 2,160 puparia (Table 3) were obtained, of them, 1,916 (88.7\%) were tephritids and $223(10.3 \%)$ were lonchaeidae, in addition to 21 parasitized puparia $(1.0 \%)$.

Infestation by frugivorous flies occurred in 14 of the 26 sampled hosts: acerola, cajá, cashew, star fruit, guava, papaya, "Haden", "Tommy Atkins" and "Rosa" mango, palm, pitanga, quiabento, seriguela and umbu. Considering infestation in pupae. $\mathrm{kg}^{-1}$ of fruit in both fruits collected from plant and soil, seriguela was the most infested host with 35.47 and 347.50 , respectively. Other hosts that stood out with infestation rates above 10 fruit pupae. $\mathrm{kg}^{-1}$ were acerola for fruits collected from the plant; star fruit and pitanga for fruits collected from the soil (Table 3).

Infestation (pupae. $\mathrm{kg}^{-1}$ of fruit) was higher in star fruit (plant) and seriguela (soil). The results obtained corroborate Sá et al. (2008) for the conditions of the fruit growing region of Anagé, BA. These authors observed infestation by fruit flies in umbu, mango, seriguela and acerola. The authors determined that, among 21 host species studied, the highest infestation rates were observed in seriguela (61.3 pupae. $\mathrm{kg}^{-1}$ of fruit), juá (38.3 pupae. $\mathrm{kg}^{-1}$ of fruit) and umbu (33.1 pupae. $\mathrm{kg}^{-1}$ of fruit), agreeing in part with data obtained in the present study. On the other hand, data from Sá et al. (2008) showed that acerola presented one of the lowest infestation rates ( 0.9 pupae. $\mathrm{kg}^{-1}$ of fruit), whereas in the present study, This result was 12.11 pupae. $\mathrm{kg}^{-1}$ of fruits for fruits collected from the plant. For the conditions of Mossorró, RN, the infestation in acerola was 199.4 pupae. $\mathrm{kg}^{-1}$ (ARAÚJO et al., 2011). The infestation rate in pitanga was 25.0 pupae. $\mathrm{kg}^{-1}$ of fruits (soil); however, Melo et al. (2012) obtained infestation rate of 263.1 pupae. $\mathrm{kg}^{-1}$ of fruits.

The infestation rate in guava and umbu was 0.17 pupae.fruit $^{-1}$ (plant) and 0.19 pupae.fruit $^{-1}$ (soil), respectively, lower than the rates obtained by
Alvarenga et al. (2009) in guava and umbu, which reached 1.70 and 1.74 pupae. fruit $^{-1}$, respectively.

A total of 1,282 adult flies were obtained, of which $1,199(93.5 \%)$ tephritids and $83(6.5 \%)$ lonchaeidae specimens were obtained. Among tephritids, 640 (53.4\%) were C. capitata and 559 (46.6\%) Anastrepha obliqua (Macquart, 1835), and lonchaeidae of the Neosilba pendula species (Bezzi, 1919) (Table 4).

Acerola, cajá, cashew, star fruit, papaya, "Haden", "Tommy Atkins" and "Rosa" mango, palm, pitanga, quiabento and seriguela were associated with $C$. capitata; "Haden", "Tommy Atkins" mango, palm, pitanga, seriguela and umbu to A. obliqua; and acerola, cashew, guava, pitanga and seriguela to $N$. pendula, in which seriguela stands out as the only host of the three fruit fly species, also associated to parasitoids Utetes anastrephae (Viereck, 1913) and Doryctobracon areolatus (Szépigeti, 1911 ) (Table 4).

Low diversity of tephritids was observed in the present study in relation to other works already conducted fruit growing regions of Bahia. Considering commercial orchards of the same fruit growing region (Livramento de Nossa Senhora), Aguiar (2012), through collections with McPhail traps from 2006 to 2009, found C. capitata, A. obliqua, A. fraterculus, Anastrepha serpentina (Wiedemann, 1830), Anastrepha sororcula Zucchi, 1979, Anastrepha zenildae Zucchi, 1979, Anastrepha grandis (Macquart, 1846), Anastrepha montei Lima, 1934, Anastrepha amita Zucchi, 1979, Anastrepha pseudoparalela (Loew, 1873), Anastrepha manihot Lima, 1934, Anastrepha pickeli Lima, 1934, Anastrepha dissimilis Stone, 1942 and Anastrepha distitncta Greene, 1934, being the first three dominant species. In the same way, Sá et al. (2012a), working in the fruit growing region of Vale do Rio Gavião, BA, which is approximately $153 \mathrm{~km}$ from the Livramento de Nossa Senhora, found at least four and a maximum of seven Anastrepha species as a function of the sampled orchard.

One of the hypotheses to explain the low diversity of c obtained in the present study is probably due to the prolonged drought that occurred in the region, covering a good part of the fruit collection period (end of 2012 to 2014). In several collections, scarcity or absence of fruits was observed, limiting the samplings process, consequently, the collection of flies.

On the other hand, low diversity of tephritids was also observed in the works of Lopes et al. (2008), who obtained only C. capitata in mandarin orchards located in Paraíba, and by Nunes et al. (2012) and 
Dias et al. (2013), who verified the occurrence of $C$. capitata and A. fraterculus in non-commercial orchards of several fruit trees in Rio Grande do Sul. Neosilba pendula occurred in acerola, cashew, guava, pitanga and seriguela in a total of 83 individuals. Seriguela and guava were reported as hosts of $N$. pendula in the southern region of the Pantanal (NICÁCIO; UCHÔA, 2011). The infestation rates by lonchaeidae in acerola collected from the plant were 12.11 pupae.kg of fruit ${ }^{-1}$ and 0.04 pupae. fruit ${ }^{-1}$, similar to data presented by Araújo and Zucchi (2002), who obtained infestation rates of 14.90 pupae.kg of fruit ${ }^{-1}$ and 0.08 pupae.kg of fruit $^{-1}$ in acerola fruits. Species belonging to the genus Neosilba were also found infesting guava in the city of Pelotas and Campo Leão, RS (NUNES et al., 2012), showing that lonchaeidae are widely distributed in Brazil, deserving greater attention in bioecological studies of frugivorous flies. Ferreira et al. (2003) identified the presence of Neosilba species infesting "Imperial" and "Tommy Atkins" mangoes, representing $29.7 \%$ of identified fruit flies, being the first record of this genus in mango fruits in the state of Goiás, which was not observed in the present study.

Parasitism occurred in Anastrepha puparia from "Tommy Atkins" mango and seriguela and in $C$. capitata puparia from star fruit, and parasitoids of the Braconidae family emerged from Anastrepha puparia and those of the Pteromalidae family emerged from C. capitata puparia. Of the 21 specimens found, $D$. areolatus occurred in a higher frequency $(90.50 \%)$ parasitizing larvae / pupae of fruit flies in mango and seriguela fruits and $U$. anastrephae $(4.75 \%)$ in larvae / pupae in seriguela and one specimen of the Pteromalidae family (4.75\%) in larvae / pupae of $C$. capitata, and this tritrophic relationship is unprecedented for the state of Bahia. Ferreira et al. (2003) found the $D$. areolatus species associated with "Imperial" and "Tommy Atkins" mango fruits, with the highest frequency $(94.1 \%)$ occurring in fruits of the "Imperial" variety. Of the 71 specimens of parasitoids found in the fruit growing region of Anagé, Bahia, $63(88.7 \%)$ were of the D. areolatus species, being the most abundant (SÁ et al., 2012b), a fact also reported in other studies (ALVARENGA et al., 2009; MARSARO JÚNIOR et al., 2011a; ARAÚJO et al., 2015).

The association acerola and $N$. pendula indicated the importance of this host for the maintenance of populations of this fly that infests several other vegetables of economic importance, such as cajarana, seriguela, acerola, guava, star fruit, juá and mandarin (ARAÚJO; ZUCCHI, 2002). Infestations by lonchaeidae of the genus Neosilba have also been observed in peach (MONTES et al., 2011) and by Neosilba and Lonchea in star fruit and papaya (DIAS et al., 2013).

Both cactaceae species were infested with tephritides, palm (O. ficus indica) by $C$. capitata and A. obliqua and quiabento (P. bahiensis) by C. capitata and Anastrepha sp., in this case, it was not possible to infer on the species because it was a male specimen. These bitrophic relationships are unprecedented, with record of infestation in Pereskia aculeata Mill. (1768) by Anastrepha barbiellinii Lima (1918) in Santa Catarina (GARCIA; NORRBOM, 2011) and by A. barbiellinii and C. capitata in Ponte Nova, MG (MARSARO JÚNIOR et al., 2011b). These bitrophic relationships are of importance to fruit growing regions of northeastern Brazil, since such hosts are common in commercial orchards aimed at external markets. Quiabento fruits may be an option for the survival of tephritids in prolonged periods of drought when the number of primary hosts is reduced (LEITE, 2016). Forage palm is a multipurpose plant cultivated in arid and semi-arid regions of northeastern Brazil (OLIVEIRA et al., 2010).

C. capitata species is polyphagous and new records of bitrophic interactions involving this fly were also reported by Araújo et al. (2016) in Garcinia acuminata Planch. \& Triana and Garcinia brasiliensis $\mathrm{C}$. Martius fruits. The high abundance of $C$. capitata was also observed in other studies carried out in the northeastern region of Brazil, like Aguiar (2012) in the fruit growing regions of Bahia; De Araújo et al. (2011) in Rio Grande do Norte; and Lopes et al. (2008) in Paraíba. Aguiar (2012) associated this aspect to the expansion of areas cultivated with different fruit trees and that probably C. capitata is exerting a strong competition on the Anastrepha species. For Silva (2012), C. capitata began to occupy areas previously filled by species of the genus Anastrepha, influencing the displacement of the native species (A. obliqua) by the invasive species ( $C$. capitata). The adaptive capacity of $C$. capitata was reported by Feitosa et al. (2007), who recorded for the first time infestation in star fruit. In the fruit growing region of Anagé, BA, Sá et al. (2008) found C. capitata infesting only mango.

Fruit flies of the genus Anastrepha are predominant under certain conditions, such as those occurring in guava crops in the southeastern region of the state of São Paulo (SÃO JOÃO et al., 2014) and in mango orchards at the fruit growing region of Itaberaba, BA (AGUIAR, 2012). In the present work, A. obliqua was the only species obtained during the study period. This species has been reported as one of the most frequent in mango orchards as observed in 
the Vale do Rio Gavião Region, BA(SÁ et al., 2012b) and in Piauí (FEITOSA et al., 2008) and in several hosts for the conditions of Roraima (MARSARO JÚNIOR et al., 2011a) and Piauí (ARAÚJO et al., 2014). On the other hand, Silva et al. (2011b) obtained three Anastrepha species in myrtle fruits in the state of Bahia, A. fraterculus, A. zenildae and A. sororcula, with no record of $A$. obliqua.
With data obtained in this study, the adaptability of $A$. obliqua to other hosts, such as cactaceae, is emphasized, and in some cases $A$. obliqua has been predominant in relation to $A$. fraterculus (SÁ et al., 2012b; AGUIAR, 2012)

TABLE 1 - Family, scientific name, common name and origin of hosts studied in the larval monitoring of frugivorous flies. Livramento de Nossa Senhora, BA, November/ 2011 to June / 2014.

\begin{tabular}{|c|c|c|c|}
\hline \multirow{2}{*}{ Family } & \multicolumn{3}{|c|}{ Host } \\
\hline & Scientific name & Common name & Origin \\
\hline \multirow{5}{*}{ Anacardiaceae } & Spondias lutea L. & Cajá & Exotic \\
\hline & Anacardium occidentale L. & Cashew & Native \\
\hline & Mangifera indica $\mathrm{L}$. & $\begin{array}{l}\text { Mango varieties: “Ataulfo, } \\
\text { Carlota, Coquinho, Espada, } \\
\text { Haden, Keit, Palmer, Rosa, } \\
\text { Tommy Atkins". }\end{array}$ & Exotic \\
\hline & Spondias purpurea L. & Seriguela & Exotic \\
\hline & Spondias tuberosa Arruda & Umbu & Native \\
\hline \multirow{2}{*}{ Cactaceae } & Opuntia ficus indica (L.) Mill & Palm & Exotic \\
\hline & Pereskia bahiensis Gürke & Quiabento & Native \\
\hline Caricaceae & Carica papaya $\mathrm{L}$. & Papaya & Exotic \\
\hline Malpighiaceae & Malpighia emarginata DC & Acerola & Exotic \\
\hline Moraceae & Morus nigra $\mathrm{L}$. & Blackberry & Exotic \\
\hline Musaceae & Musa sp. & Banana & Exotic \\
\hline \multirow{2}{*}{ Myrtaceae } & Psidium guajava L. & Guava & Exotic \\
\hline & Eugenia uniflora $\mathrm{L}$. & Pitanga & Native \\
\hline \multirow{2}{*}{ Oxalidaceae } & Averrhoa bilimbi $\mathrm{L}$ & Biri-biri & Exotic \\
\hline & Averrhoa carambola $\mathrm{L}$. & Star fruit & Exotic \\
\hline Passifloraceae & $\begin{array}{c}\text { Passiflora edulis f. flavicarpa } \\
\text { Dgener }\end{array}$ & Passion fruit & Exotic \\
\hline Rhamnaceae & Ziziphus joazeiro Mart. & Juá & Native \\
\hline \multirow[t]{2}{*}{ Rutaceae } & Citrus limonium Risso & Lemon & Exotic \\
\hline & Citrus reticulata Blanco & Mandarin & Exotic \\
\hline
\end{tabular}


TABLE 2 - Number of samples, number of fruits and fruit mass $(\mathrm{kg})$ collected from the plant, from the soil and from both (total), according to the sampled hosts. Period from November / 2011 to June / 2014, Livramento de Nossa Senhora, BA.

\begin{tabular}{|c|c|c|c|c|c|c|c|}
\hline \multirow{2}{*}{ Host } & \multirow{2}{*}{$\begin{array}{c}\mathrm{N}^{\circ} \text {. of } \\
\text { samples }\end{array}$} & \multicolumn{3}{|c|}{$\mathrm{N}^{\circ}$. of fruits } & \multicolumn{3}{|c|}{ Fruit mass (kg) } \\
\hline & & Soil & Plant & Total & Soil & Plant & Total \\
\hline Acerola & 17 & 2,264 & 4,440 & 6,704 & 6.20 & 13.38 & 19.58 \\
\hline Blackberry & 1 & - & 120 & 120 & - & 0.11 & 0.11 \\
\hline Banana & 1 & - & 18 & 18 & - & 1.55 & 1.55 \\
\hline Biri biri & 1 & 48 & 19 & 67 & 0.64 & 0.16 & 0.80 \\
\hline Cajá & 3 & 25 & 10 & 35 & 2.44 & 0.76 & 3.20 \\
\hline Cashew & 11 & 95 & 125 & 220 & 5.39 & 7.22 & 12.61 \\
\hline Star fruit & 44 & 602 & 1,801 & 2,403 & 31.98 & 107.63 & 139.61 \\
\hline Guava & 3 & 17 & 6 & 23 & 1.11 & 0.77 & 1.88 \\
\hline Juá & 9 & 1,808 & 1.282 & 3,090 & 3.81 & 3.40 & 7.21 \\
\hline Lemon & 3 & 49 & 111 & 160 & 3.99 & 11.40 & 15.49 \\
\hline Papaya & 30 & 90 & 171 & 261 & 30.39 & 63.21 & 93.60 \\
\hline Ataulfo Mango & 1 & 18 & - & 18 & 3.52 & - & 3.52 \\
\hline Carlota Mango & 1 & 66 & - & 66 & 9.87 & - & 9.87 \\
\hline Coquinho Mango & 1 & 14 & 14 & 28 & 2.06 & 2.20 & 4.26 \\
\hline Keit Mango & 1 & - & 16 & 16 & - & 4.60 & 4.60 \\
\hline Espada Mango & 12 & 124 & 23 & 147 & 29.92 & 4.88 & 34.80 \\
\hline Haden Mango & 5 & 12 & 14 & 26 & 5.84 & 5.39 & 11.23 \\
\hline Palmer Mango & 6 & 19 & 28 & 47 & 6.88 & 13.85 & 20.73 \\
\hline Rosa Mango & 48 & 803 & 348 & 1,151 & 192.30 & 89.35 & 281.65 \\
\hline Tommy Mango & 64 & 1,229 & 926 & 2,155 & 518.98 & 354.94 & 873.92 \\
\hline Passion fruit & 19 & 385 & 112 & 497 & 43.82 & 10.33 & 54.15 \\
\hline Palm & 13 & - & 485 & 485 & - & 40.97 & 40.97 \\
\hline Quiabento & 19 & 864 & 1,121 & 1985 & 19.70 & 25.47 & 45.17 \\
\hline Pitanga & 5 & 88 & 188 & 276 & 0.24 & 0.56 & 0.80 \\
\hline Seriguela & 15 & 60 & 1,640 & 1,700 & 0.40 & 15.79 & 16.19 \\
\hline Mandarin & 4 & 4 & 172 & 176 & 0.50 & 12.10 & 12.60 \\
\hline Umbu & 12 & 959 & 538 & 1,497 & 22.53 & 14.51 & 37.04 \\
\hline Total & 345 & 9,643 & 13,728 & 23,371 & 942.51 & 804.53 & $1,747.04$ \\
\hline
\end{tabular}


TABLE 3 - Number of puparia (No.) and infestation rates (pupae. $\mathrm{kg}^{-1}$ of fruit and pupae.fruit ${ }^{-1}$ ) in fruits collected from the plant and soil as a function of the hosts. Period from November / 2011 to June / 2014, Livramento de Nossa Senhora, BA.

\begin{tabular}{|c|c|c|c|c|c|c|}
\hline \multirow[b]{2}{*}{ Host } & \multirow[b]{2}{*}{ Puparia $\left(\mathrm{N}^{\circ}\right.$.) } & \multicolumn{2}{|c|}{ Infestation rate (Plant) } & \multirow[b]{2}{*}{ Puparia ( $\mathrm{N}^{\mathrm{o}}$.) } & \multicolumn{2}{|c|}{ Infestation rate (Soil) } \\
\hline & & $\begin{array}{c}\text { Pupae.kg-1 } \\
\text { of fruit }\end{array}$ & Pupae. fruit $^{-1}$ & & $\begin{array}{c}\text { Pupae.kg-1 } \\
\text { of fruit }\end{array}$ & Pupae. fruit ${ }^{-1}$ \\
\hline Acerola & 162 & 12.11 & 0.04 & 15 & 2.42 & 0.001 \\
\hline Cajá & 1 & 1.32 & 0.10 & - & - & - \\
\hline Cashew & 19 & 2.63 & 0.15 & 11 & 2.04 & 0.12 \\
\hline Star fruit & 482 & 4.48 & 2.28 & 433 & 13.54 & 0.72 \\
\hline Guava & 1 & 1.30 & 0.17 & - & - & - \\
\hline Papaya & 15 & 0.24 & 0.09 & - & - & - \\
\hline Haden Mango & 25 & 4.63 & 1.79 & - & - & - \\
\hline Rosa Mango & - & - & - & 14 & 0.07 & 0.002 \\
\hline Tommy Mango & 111 & 0.31 & 0.12 & 66 & 0.13 & 0.05 \\
\hline Palm & 3 & 0.08 & 0.001 & - & - & - \\
\hline Pitanga & 5 & 8.93 & 0.03 & 6 & 25.00 & 0.07 \\
\hline Quiabento & 2 & 0.08 & 0.001 & - & - & - \\
\hline Seriguela & 560 & 35.47 & 0.34 & 139 & 347.50 & 2.32 \\
\hline Umbu & 12 & 1.57 & 0.04 & 78 & 7.10 & 0.19 \\
\hline Total & 1398 & & & 762 & & \\
\hline
\end{tabular}

TABLE 4 - Species of frugivorous flies (Tephritidae and Lonchaeidae) obtained in fruits collected from the plant and soil, according on the host. Period from November / 2011 to June / 2014, Livramento de Nossa Senhora, BA.

\begin{tabular}{|c|c|c|c|c|c|c|c|}
\hline \multirow{3}{*}{ Host } & \multicolumn{4}{|c|}{ Tephritidae } & \multicolumn{2}{|c|}{ Lonchaeidae } & \multirow{3}{*}{ Parasitoids } \\
\hline & \multicolumn{6}{|c|}{ Ceratitis capitata Anastrepha obliqua Neosilba pendula } & \\
\hline & Plant & Soil & Plant & Soil & Plant & Soil & \\
\hline Acerola & 4 & 2 & 0 & 0 & 44 & 12 & \\
\hline Cajá & 1 & 0 & 0 & 0 & 0 & 0 & \\
\hline Cashew & 0 & 2 & 0 & 0 & 9 & 0 & \\
\hline Star fruit & 264 & 162 & 19 & 51 & 1 & 0 & Pteromalidae \\
\hline Guava & 0 & 0 & 0 & 0 & 1 & 0 & \\
\hline Papaya & 15 & 0 & 0 & 0 & 0 & 0 & \\
\hline Haden Mango & 22 & 0 & 2 & 0 & 0 & 0 & \\
\hline Rosa Mango & 1 & 1 & 3 & 0 & 0 & 0 & \\
\hline Tommy Mango & 86 & 43 & 1 & 0 & 0 & 0 & Doryctobracon areolatus \\
\hline Palm & 1 & 0 & 2 & 0 & 0 & 0 & \\
\hline Pitanga & 0 & 3 & 3 & 0 & 0 & 3 & \\
\hline Quiabento & 1 & 0 & 1 & 0 & 0 & 0 & \\
\hline Seriguela & 24 & 8 & 353 & 110 & 12 & 1 & $\begin{array}{c}\text { Doryctobracon areolatus and } \\
\text { Utetes anastrephae }\end{array}$ \\
\hline Umbu & 0 & 0 & 2 & 12 & 0 & 0 & \\
\hline Total & 419 & 221 & 386 & 173 & 67 & 16 & \\
\hline
\end{tabular}




\section{CONCLUSIONS}

In the fruit growing region of Livramento de Nossa Senhora, BA, the occurrence of frugivorous flies Anastrepha obliqua, Ceratitis capitata and Neosilba pendula has been reported.

Anacardium occidentale, Averrhoa carambola, Carica papaya, Eugenia uniflora, Malpighia emarginata, Mangifera indica var. "Haden", "Rosa" and "Tommy Atkins", Opuntia ficus indica, Pereskia bahiensis, Psidium guajava, Spondias lutea, Spondias purpurea and Spondias tuberosa are hosts of frugivorous flies in the region.

Unprecedented bitrophic relationships between P. bahiensis and C. capitata and Anastrepha sp. and between Opuntia ficus indica and C. capitata and $A$. oblique were recorded.

Unprecedented tritrophic relationships for the state of Bahia Averrhoa carambola and Ceratitis capitata and parasitoid of the Pteromalidae family was also recorded.

Tritrophic associations between Mangifera indica var. "Tommy Atkins" and Spondias purpurea and Anastrepha obliqua and Doryctobracon areolatus; and between Spondias purpurea and Anastrepha obliqua and Utetes anastrephae were also verified.

\section{ACKNOWLEDGMENTS}

To the Coordination for the Improvement of Higher Education Personnel (CAPES), for granting the master's degree to the first author; to the Graduate Program in Agronomy of the State University of Southwestern Bahia-UESB; to collaborating institutions CAPES, ADAB and UESB. To Professor Avaldo de Oliveira Soares Filho for the identification of the Pereskia bahiensis plant species

\section{REFERENCES}

AGUIAR,W. M. M. Moscas-das-frutas (Dip. Tephritidae) de importância econômica no Estado da Bahia - biodiversidade e perfil do consumidor de manga no mercado interno. 2012. $84 \mathrm{f}$. Dissertação (Mestrado em Defesa Agropecuária) Universidade Federal do Recôncavo Bahia, Cruz das Almas, 2012.
ALVARENGA, C.D.; MATRANGOLO, C.A.R; LOPES, G.N.; SILVA, M.A.; LOPES, E.N.; ALVES, D.A.; NASCIMENTO, A.S.; ZUCCHI, R.A. Moscasdas-Frutas (Diptera: Tephritidae) e seus parasitoides em plantas hospedeiras de três municípios do norte do estado de Minas Gerais. Arquivos do Instituto Biológico, São Paulo, v.76, n.2, p.195-204, 2009.

ARAÚJO, A.A.R.; SILVA, P.R.R.; QUERINO, R.B; SOUSA, E.P. de S.; SOARES, L.L. Moscas-dasfrutas (Diptera: Tephritidae) associadas as frutíferas nativas de Spondias spp. (Anacardiaceae) e Ximenia americana L. (Olacaceae) e seus parasitoides no estado do Piauí, Brasil. Semina: Ciências Agrárias, Londrina, v.35, n.4, p.1739-1750, 2014.

ARAÚJO, E.L.; FERNANDES, E.C.; SILVA, R.I.R.; FERREIRA, A.D.C. de L.; COSTA, V.A. da Parasitoides (Hymenoptera) de moscas-das-frutas (Diptera: Tephritidae) no semiárido do estado do Ceará, Brasil. Revista Brasileira de Fruticultura, Jaboticabal, v.37, n.3, p.610-616, 2015.

ARAÚJO, E.L.; LOPES, P.A. da R.; GOMES, J.G. da; BITTENCOURT, M.A.L.; RONCHI-TELES, B. Índices de captura e infestação da mosca do mediterrâneo em acerola comum e clonada. Revista Verde, Mossoró, v.6, n.4, p.58-64, 2011.

ARAÚJO, E.L.; ZUCCHI, R.A. Hospedeiros e níveis de infestação de Neosilba pendula (Bezzi) (Diptera: Lonchaeidae) na região de Mossoró/Assu, RN. Arquivos do Instituto Biológico, São Paulo, v.69, n.2, p.91-94, 2002.

ARAUJO, M.R. de; LEMOS, W. de P.; SILVA, L.C. da; FRANÇA, L.P.N.; ADAIME, R. New host records for Ceratitis capitata (Diptera: Tephritidae) in state of Pará, Brasil. Florida Entomologist, Gainesville, v.99, n.2, p.327-328, 2016.

BITTENCOURT, M. A. L.; SANTOS, O.O. dos; BRITO, E. dos A.; ARAÚJO, E.L.; MARINHO, C.F. Parasitoides (Braconidae) associados à Anastrepha (Tephritidae) em frutos hospedeiros do Litoral Sul da Bahia. Revista Ciência Agronômica, Fortaleza, v.43, n.4, p. 811-815, 2012.

DIAS, N.P.; SILVA, F.F. da; ABREU, J.A. de; PAZINI, J. de B.; BOTTA, R. A. Nível de infestação de moscas-das-frutas em faixa de fronteira no Rio Grande do Sul. Revista Ceres, Viçosa, MG, v.60, n.4, p.589-593, 2013. 
FEITOSA, S.S.; SILVA, P.R.R.; PÁDUA, L.E. de M.; CARVALHO, E.M.S.; PAZ, J.K. da S.; PAIVA, D.R. de. Flutuação populacional de moscas-dasfrutas (Diptera: Tephritidae) associadas a variedades de manga no município De José de Freitas-Piauí. Revista Brasileira Fruticultura, Jaboticabal, v.30, n.1, p.112-117, 2008.

FEITOSA, S.S.; SILVA, P.R.R.; PÁDUA, L.E. de M.; SOUSA, M.P. da S.; PASSOS, E. P. de; SOARES, A.A.R.A. Primeiro registro de moscas-das-frutas (Diptera: Tephritidae) em carambola nos municípios de Teresina, Altos e Parnaíba no estado do Piauí. Semina: Ciências Agrárias, Londrina, v.28, n.4, p.629-634, 2007.

FERREIRA, H.J.; VELOSO, V. da R.S.; NAVES, R.V.; BRAGA FILHO, J.R. Infestação de moscasdas-frutas em variedades de manga (Mangifera indica L.) no estado de Goiás. Pesquisa Agropecuária Tropical, Goiânia, v.33, n.1, p.43-48, 2003.

GARCIA, F.R.M.; NORRBOM, A.L. Tephritoid flies (Diptera, Tephritoidea) and their plant hosts from the state of Santa Catarina in southern Brazil. Florida Entomologist, Gainesville, v.94, n.2, p. 151-157, 2011.

LEITE, S.A. Aspectos bioecológicos das moscas frugívoras no polo fruticultura de Livramento de Nossa Senhora, BA, e em laboratório. 2016, 115f. Dissertação (Mestrado em Agronomia) Universidade Estadual do Sudoeste da Bahia, Vitória da Conquista, 2016.

LOPES, E. B.; BATISTA, J. de L.; ALBUQUERQUE, I.C. de; BRITO, C.H. de. Moscas Frugívoras (Tephritidae e Lonchaeidae) ocorrência em pomares comerciais de tangerina (Citrus reticulata Blanco) do município de Matinhas, Estado da Paraíba. Acta Scientiarum Agronomy, Maringá, v.30, p.639-644, 2008. Suplemento

MARINHO, C.F.; SILVA, R.A. da; ZUCCHI, R. A. Chave de identificação de Braconidae (Alysiinae e Opiinae) parasitoides de larvas frugívoras na região Amazônica. In: SILVA, R. A.de; LEMOS, W.de P.; ZUCCHI, R.A. (Ed.). Moscas-das-frutas na Amazônia brasileira: diversidade, hospedeiros e inimigos naturais. Macapá: Embrapa Amapá, 2011. p.91-101.
MARSARO JÚNIOR, A.L.; ADAIME, R.; RONCHITELES, B.; LIMA, C.R.; PEREIRA, P.R.V. da S. Anastrepha species (Diptera: Tephritidae), their hosts and parasitoids in the extreme north of Brazil. Biota Neotropica, Campinas, v.11, n.4, p.117-123, 2011a.

MARSARO JÚNIOR, A.L.; SOUZA-FILHO, M.F. de; SILVA, R.A. da; STRIKIS, P.C. First report of natural infestation of Pereskia aculeata Mill. (Cactacea) by Ceratitis capitata (Wiedemann) (Diptera: Tephritidae) in Brazil. Revista de Agricultura, Piracicaba, v.86, n.2, p.152-154, 2011b.

MELO, E.A. dos S. F.; SANTOS, E. dos; ALMEIDA, F.R.; ROCHA, R.B.; SANTOS, O.O. dos; STRIKIS, P.C.; BITTENCOURT, M.A.L. Hospedeiros, níveis de infestação e parasitoides de moscas frugívoras (Diptera: Tephritidae e Lonchaeidae) em municípios da região Sul da Bahia. Magistra, Cruz das Almas, v.24, p. 08-16, 2012. Número especial

MONTES, S.M.N.M.; RAGA, A.; BOLIANI, A.C.; SANTOS, P. C. dos. Dinâmica populacional de moscas-das-frutas e parasitoides em cultivares de pessegueiros (Prunus persica L. Batsch) no município de Presidente Prudente - SP. Revista Brasileira de Fruticultura, Jaboticabal, v.33, n.2, p.402-411, 2011.

NASCIMENTO, A. S. do; CARVALHO, R. da S.; MALAVASI, A. Monitoramento Populacional. In: MALAVASI, A.; ZUCCHI, R.A. (eds.). Moscasdas-frutas de importância econômica no Brasil. Conhecimento básico e aplicado. Ribeirão Preto: Holos, 2000. p.109-112.

NICÁCIO, J.; UCHÔA, M.A. Diversity of frugivorous flies (Diptera: Tephritidae and Lonchaeidae) and their relationship with host plants (Angiospermae) in environments of south Pantanal Region, Brazil. Florida Entomologist, Gainesville, v.94, n.3, p.443466, 2011.

NUNES, A.M.; MÜLLER, F.A.; GONÇALVES, R. da S.; GARCIA, M.S.; COSTA, V.A.; NAVA, D.E. Moscas frugívoras e seus parasitoides nos municípios de Pelotas e Capão do Leão, Rio Grande do Sul, Brasil. Ciência Rural, Santa Maria, v.42, n.1, p.612, 2012. 
OLIVEIRA, F.T.; SOUTO, J.S.; SILVA, R.P.; ANDRADE FILHO, F.C.; PEREIRA JÚNIOR, E.B. Palma forrageira: Adaptação e importância para os ecossistemas áridos e semiáridos. Revista Verde, Mossoró, v.5, n.4, p.27-37, 2010.

SÁ, R.F. de; CASTELLANI, M.A.; NASCIMENTO, A.S. do; BRANDÃO, M.H. da S.T.; SILVA, A.N. da; PÉREZ-MALUZ, R. Índice de infestação e diversidade de moscas-das-frutas em hospedeiros exóticos e nativos no polo de fruticultura de Anagé, BA. Bragantia, Campinas, v.67, n.2, p.401- 411, 2008.

SÁ, R.F. de; CASTELLANI, M.A.; RIBEIRO, A.E.L.; PÉREZ-MALUZ, R.; MOREIRA, A.A.; NAGAMOTO, N.S.; NASCIMENTO, A.S. do. Faunal analysis of the species Anastrepha in the fruit growing complex Gavião River, Bahia, Brazil. Bulletin of Insectology, Bologna, v.65, n.1, p37-42, $2012 \mathrm{a}$.

SÁ, R.F.de; CASTELLANI, M.A.; NASCIMENTO, A.S. do; RIBEIRO, A.E.L.; MOREIRA, A.A. Parasitismo natural em moscas-das-frutas (Diptera: Tephritidae) no aemiárido do audoeste da Bahia, Brasil. Revista Brasileira de Fruticultura, Jaboticabal, v.34, n.4, p.1266-1269, 2012b.

SÃO JOÃO, R.E.; MONTES, S.M.N.M.; RAGA, A. Fruit flies in a guava orchard in Indiana country, São Paulo, southeastern Brazil. Idesia, Arica, v.32, n.3, p.101-107, 2014.

SEI - Superintendência de Estudos Econômicos e Sociais da Bahia. SIM - Sistema de Informações Municipais. 2015. Disponível em: $<$ http://sim. sei.ba.gov.br/sim/informacoes municipais.wsp $>$. Acesso em: 20 mar. 2015.
SILVA, D.R. de B. Influência de dois mecanismos de competição entre Anastrepha obliqua e Ceratitis capitata (Diptera: Tephritidae) na ocupação do fruto hospedeiro manga (Mangifera indica 1.). 2012. 44 f. Dissertação (Mestrado) - Universidade Federal da Bahia, Salvador, 2012

SILVA, R.A.da; DEUS, E. da G. de; RAGA, A.; PEREIRA, J.D.B.; SOUZA-FILHO, M.F. de; COSTA NETO, S.V. da. Monitoramento de moscasdas-frutas na Amazônia: amostragem de frutos e uso de armadilhas. In: SILVA, R. A.de; LEMOS, W.de P.; ZUCCHI, R.A. (Ed.). Moscas-das-frutas na Amazônia Brasileira: diversidade, hospedeiros e inimigos naturais. Macapá: Embrapa Amapá, 2011a. p.33-50.

SILVA, L.N.; SANTOS, M.S.; DUTRA, V.S.; ARAÚJO, E.L.; COSTA, M. A.; SILVA, J. G. First survey of fruit fly (Diptera: Tephritidae) and parasitoid diversity among Myrtaceae fruit across the state of Bahia, Brazil. Revista Brasileira de Fruticultura, Jaboticabal, v.33, n.3, p.757-764, 2011b.

SOUZA FILHO, M.F.; RAGA, A.; ZUCCHI R.A. Moscas-das-frutas nos estados brasileiros: São Paulo. In: MALAVASI, A.; ZUCCHI, R.A. (Ed.). Moscasdas-frutas de importância econômica no Brasil. Ribeirão Preto: Holos, 2000. p.277-283.

ZUCCHI, R.A. Fruit flies in Brazil - Hosts and parasitoids of the Mediterranean fruit fly. Piracicaba: ESALQ, 2012. Disponível em: $\leq$ http:// www.lea.esalq.usp.br/fruitflies/ $>$. Acesso em: 10 abr. 2015.

ZUCCHI, R.A. Taxonomia. In: MALAVASI, A.; ZUCCHI, R.A. (Ed.). Moscas-das-frutas de importância econômica no Brasil. Conhecimento básico e aplicado. Ribeirão Preto: Holos, 2000 p.13-24. 